\title{
Cognitive Learning Styles Of EFL Students
}

\author{
Napaporn Srichanyachon, Bangkok University, Thailand
}

\begin{abstract}
This study aimed to study cognitive learning styles of EFL students, compare language learning styles among students categorized by their background, and investigate the relationship between English background knowledge and language learning styles. The samples were 210 undergraduate students enrolled in Fundamental English course at Bangkok University. The instrument in this study was a questionnaire. Results indicated that the overall language learning style was at a moderate level. There were significant differences at .05 level found in students' language learning styles as classified by gender, but no statistically significant differences in terms of field of study. In addition, there was a positive relationship between English background knowledge and language learning styles at .05 level.
\end{abstract}

Keywords: cognitive; learning style; EFL students

\section{INTRODUCTION AND THEORETICAL FRAMEWORK}

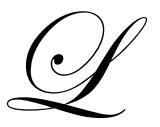

earning is an aspect of human cognition. It is not about how much you know, but how effectively you handle the information you receive. In certain kinds of second language learning situations, language teachers have to consider that learners differ consistently from each other in their preferences for certain ways of processing information. The way a person prefers to learn is called his/her learning style. According to Pask (1976), knowing one's learning style is important in learning. However, Mulalic, Shah and Ahmad (2009) points out that students' learning styles have been ignored and have been considered as an insignificant component in the learning process.

\section{Definitions of Cognitive/Learning Styles}

Cognitive style is a term used in cognitive psychology. It deals with the 'form' of cognitive activity (i.e. thinking, perceiving, remembering), not its content (Stash, 2007). Descriptions of cognitive style include: a person's preferred and habitual approach to organizing and representing information (Riding \& Rayner, 1998); relatively stable indicators of how learners perceive and interpret information, and respond to learning environments (Wolfe \& Johnson, 1995); variations in individual information processing (Heineman, 1995); the styles as personality dimensions that influence how an individual collects, analyses, evaluates and interprets information (Harrison \& Rainer, 1992); the information processing habits of individual learners (Keefe, 1991); a person's typical modes of perceiving, remembering, thinking and problem solving (Messick 1970); and an individual's preferred mode of information processing, particularly field independency (Witkin, 1950).

Learning styles are described by different researchers as: a coherent whole of learning activities that students usually employ, their learning orientation and their mental model of learning (Vermunt, 1996); a description of the attitudes and behavior which determine an individual's preferred way of learning (Honey \& Mumford, 1992); preferences for one mode of adaptation over the others; but these preferences do not operate to the exclusion of other adaptive modes and will vary from time to time and situation to situation (Kolb, 1981); and cognitive, affective and physiological traits that are relatively stable indicators of how learner perceive, interact with, and respond to the learning environment (Keefe, 1979).

Various definitions of cognitive and learning styles are provided by different authors, but no universally recognized definition has been identified (Heineman, 1995; Stash, 2007). Moreover, numerous authors use the terms cognitive style and learning style interchangeably (Heineman, 1995; Liu and Ginther, 1999). Most definitions of 
learning style as well as cognitive style, illustrate variations in individual information processing (McFadden,1986). However, there is a difference between cognitive and learning styles. A major difference between the terms cognitive and learning styles is that cognitive styles are more related to a bipolar dimension while learning styles are not necessarily either/or extremes (Liu and Ginther, 1999). Tyacke (1998) points out that learning styles can be regarded as cognitive styles which determine an individual's mode of perceiving, thinking and problem solving since they are conceptualised from stable attitudes, preferences or habitual strategies. On the other hand, Keefe (1979) points out that learning style is seen as a broader construct, which includes cognitive along with affective and psychological styles.

In this dissertation the researcher will refer to the terms cognitive and learning styles interchangeably. Mostly the broader term learning styles will be used. In addition, it is necessary to make a distinction between styles and ability. Sternberg (1999) points out that a style is not about how much you know, but how effectively you process or handle the information you receive. On the other hand, an ability refers to how well someone can do something. Therefore, a style refers to how someone likes to do something.

\section{Kolb's Learning Style Inventory (LSI)}

Kolb's Learning Style Inventory (LSI) remained one of the most influential and widely distributed instruments used to measure individual learning preference (Kayes, 2005). According to Kolb (1984), learning is the process whereby knowledge is created through the transformation of experience. Knowledge results from the combination of grasping experience and transforming it. A central principle of his experimental learning theory is a four stage 'cycle of learning' that includes the following learning modes:

1. Concrete Experience (CE - feeling): the ability to be involved in new experiences without bias or restraint

2. Abstract Conceptualization (AC - thinking): the ability to theorize logically, and to integrate observation into concepts

3. Active Experimentation (AE - doing): the ability to act by making decisions and problem solving

4. Reflective Observation (RO - watching): the ability to maintain multiple perspectives in observation and contemplation

Based on the four learning modes, there are four basic learning styles, each representing the combination of two learning modes (Figure 1):

Figure 1: Kolb's Learning Styles Model (“Experiential Learning,” 2002)

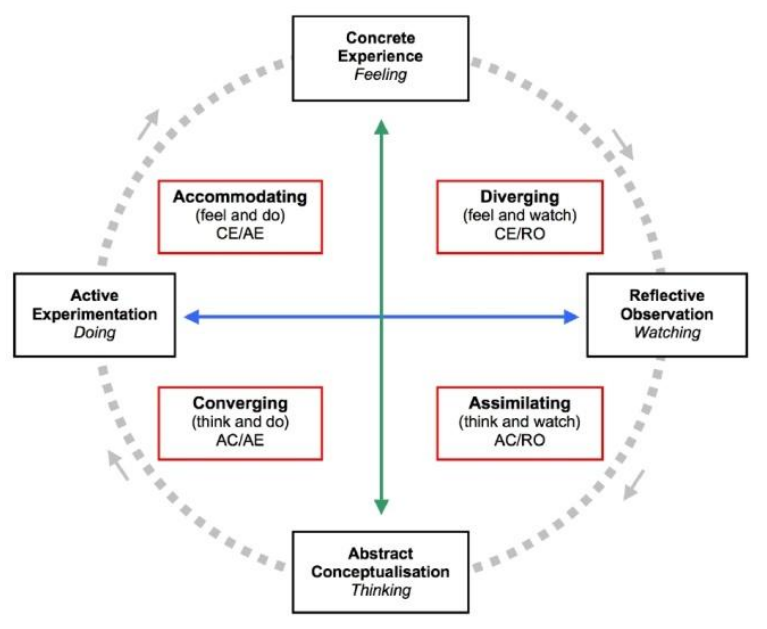


According to Kolb (1985), no single mode entirely describes one's learning style. This is because each person's learning style is a combination of four basic learning modes. Kolb (1984) describes people who fall into these four categories as follows:

1. Diverging style (CE/RO): People with this style have the ability to view concrete situations from several different viewpoints and approach problems through observation rather than action. They tend to gather information and use imagination to solve problems. They prefer to work in groups, to listen with an open mind and to receive personal feedback. A characteristic question of this learning type is "Why?". This type of learners responds well to explanations of how course material relates to their experience, interests, and future careers.

2. Assimilating style (AC/RO): People with the this style have strengths in understanding a wide range of information and putting it into concise, logical form. Similar to people with convergent style, these people are less focused on people and more interested in abstract concepts. However, they tend to focus more on logical soundness and preciseness of the ideas, rather than their practical values. They prefer readings, lectures, exploring analytical models, and having time to think. A characteristic question of this learning type is "What?". This type of learners responds to information presented in an organized, logical fashion and benefit if they have time for reflection.

3. Converging style (AC/AE): People with this style use their learning to find solutions to practical issues. They prefer technical tasks, and are less concerned with people. They can solve problems and make decisions based on finding solutions to questions or problems. They like to experiment with new ideas, to simulate, and to work with practical applications. A characteristic question of this learning type is "How?". This type of learners responds to having opportunities to work actively on well-defined tasks and to learn by trial-and-error in an environment that allows them to fail safely.

4. Accommodating style (CE/AE): People who fall into this style learn from hand-on activities and rely on intuition rather than logic. These people use other people's analyses, and prefer to take a practical, experimental approach. They tend to rely on others for information rather than technical analyses. People with this learning style prefer to work in teams to complete tasks. A characteristic question of this learning type is "What if?". This type of learners likes applying course material in new situations in order to solve real problems.

\section{Learning Styles: Assessment and Intervention}

Ichikawa (2001, cited in Shwalb, Nakazawa, and Shwalb, 2005) points out that learning styles that are based on cognitive theory may be called "cognitive" learning styles. He provides the guidelines for counselors to intervene with clients who have non-cognitive learning styles as follows:

1. Be strategic to teach yourself. The effect of learning depends on your learning methods. You must choose which method to adopt because you are responsible for teaching yourself. You should know, discover, and try out several methods of learning.

2. Organize knowledge. Knowledge can be stored and recalled well by organization. Making tables and figures for yourself is a useful way to make your knowledge more systematic. You should try to understand about causality and structure when you learn new facts or procedures.

3. Be process-oriented. If you think appropriately but answer incorrectly because of a small mistake, you will successfully solve the problems on your next try as long as you can easily correct the mistake. So, it is the most critical for you to use the appropriate process to solve a problem.

4. Utilize failures as part of learning. Failures in learning are actually chances to get more information about your knowledge. If you fail to solve a problem, you should draw some lessons about the cause of failure, whether it was due to a mistake, a misconception, an incorrect procedure, or a lack of knowledge.

Ichikawa also developed a questionnaire to assess cognitive versus non-cognitive learning styles. The four scales with six items are formulated to elicit learners' styles. Several investigations of high school and college students have shown that the scales are inter-correlated (Shwalb, Nakazawa, and Shwalb, 2005). 
There is no agreement on the number or variety of learning styles. A number of learning style models can be found in the research on this subject. Also, there is no evidence that one type of learner is more successful than the other type (Rubin \& Thompson, 1994). There is no right or wrong/good or bad learning style. What is more important is that the learner's style be appropriate to the particular task. Therefore, the main question of this research is simply: How do language learners come to know elements of the language they learn? The main goal will be to accommodate each learner's preferences in the classroom.

\section{PURPOSES OF THE STUDY}

The objectives of this study were:

1. to study cognitive learning styles of EFL students.

2. to compare language learning styles of students with different background (gender and field of study).

3. to investigate the relationship between English background knowledge and language learning styles.

\section{RESEARCH METHODOLOGY}

\section{Population and Samples}

The participants included in this study were undergraduate students enrolled in Fundamental English course at Bangkok University. These students studied English as a foreign language. The samples were selected by the use of stratified random sampling technique. As a result, 210 students were participated in the data collection.

\section{Research Instrument}

In order to identify students' cognitive learning styles, a questionnaire was used to collect the data. The first part gathered personal information from the respondents who are asked to answer the questions on gender, field of study, and English background knowledge. This general background might have something to do with students' language learning styles. The second part was a survey of cognitive styles adopted from Ichikawa (2001, cited in Shwalb, Nakazawa, and Shwalb, 2005). To respond this part, the respondents were asked to check their language learning styles in terms of methods: strategy-orientation, meaning-orientation, process-orientation, and failure-resilience. The questionnaire was prepared for rating in a form of five-rating scale.

\section{Data Analysis}

The acceptable statistical significance level was set at alpha $(\alpha)<.05$. After the receipt of the completed quetionnaires, the data were statistically analyzed by using SPSS/Window 12 through the following steps:

1. The data of personal information were brought to calculate for average means.

2. The data of language learning styles were brought to calculate for average means and standard deviation.

3. The means of language learning styles were divided into three levels and interpreted in the form of range based on the criterion of $\overline{\mathrm{X}} \pm .5 \mathrm{SD}$.

- $\quad$ The average mean of language learning styles was 3.40 and standard deviation was .34.

$$
3.40 \pm(.5)(.34) \rightarrow 3.40 \pm .17
$$

\begin{tabular}{|c|c|}
\hline Level of Language Learning Styles & Mean Range \\
\hline high & $3.58-5.00$ \\
\hline moderate & $3.23-3.57$ \\
\hline low & $1.00-3.22$ \\
\hline
\end{tabular}

4. The independent-samples t-test was used to test the mean scores of two groups of subjects concerning their language learning styles. 
5. The One-Way Analysis of Variance (ANOVA) test was used to compare mean scores of three and more groups concerning their language learning styles. Then the Scheffe test was used to test a statistically significant difference in the mean scores of any two groups.

6. The Pearson product-moment correlation coefficient test was used to investigate the relationship between English background knowledge and language learning styles.

\section{RESULTS}

\section{Results of Fundamental Analysis}

1.1 Information of Language Learning Styles of EFL students

According to the student's preferences of the learning activities, the high-scoring activities are as follows.

1. The only way to attain high achievement is to practice a lot. (4.40)

2. I think things become gradually perfect by overcoming failures. (3.82)

3. I am interested in the way of learning used by successful students. (3.78)

4. After exams, I worry about whether my answer was correct or not rather than about my way of solving the problem. (3.74)

5. I often try to figure out the reason when I fail in learning. (3.68)

6. I reconsider my way of learning when I fail at exams. (3.67)

7. I make an effort when something does not go as well as I plan. (3.66)

8. I wish to know how to solve the problem that I could not answer on an exam (3.62)

9. The process of problem-solving is important for me as well as answering correctly. (3.60)

10. I try to figure out relationships among knowledge. (3.59)

11. It seems most important to memorize formulae well when learning English. (3.58)

From the findings, it was interesting to discover that three from the high-scoring activities represented failure-resilience learning style (items no. 2, 5, and 7), three activities were strategy-orientation learning style (items no. 1, 3, and 6), and the other three were process-orientation learning style (items no. 4, 8, and 9). In other words, the students tried to figure out the cause of failure and made an effort to overcome failures. They believed that the only way to attain high achievement was to practice a lot and were interested in the way of learning used by successful students. They reconsidered their way of learning when they failed at exams. After exams, they worried whether their answer was correct or not and wish to know how to solve the problem that they could not answer on an exam. Also, they realized that the process of problem-solving was important as well as answering correctly.

It is very common for learners to have more than one learning style. However, meaning-orientation learning style seemed to be the least influential one to the students. This means the students did not make their knowledge more systematic. They didn't try to understand about causality and structure when they learned new facts or procedures.

\subsection{Level of Language Learning Styles}

The study revealed that the overall of language learning style was at a moderate level ( $\bar{X}=3.40)$. Among four items of language learning style, the highest means were failure-resilience, strategy-orientation, and processorientation respectively ( $\overline{\mathrm{X}}=3.49,3.43,3.37$ ). The lowest mean falling on meaning-orientation was at a moderate level ( $\overline{\mathrm{X}}=3.31$ ). The results were presented in Table 1 .

Table 1 Mean and Standard Deviation of Language Learning Styles

\begin{tabular}{lccc}
\hline Language Learning Style & $\overline{\mathrm{X}}$ & S.D. & Level \\
\hline 1. Strategy-Orientation & 3.43 & .42 & moderate \\
2. Meaning-Orientation & 3.31 & .47 & moderate \\
3. Process-Orientation & 3.37 & .54 & moderate \\
4. Failure-Resilience & 3.49 & .46 & moderate \\
\hline Total & 3.40 & .34 & moderate \\
\hline
\end{tabular}




\section{Results of Hypothesis Testing}

\subsection{Hypothesis 1 compared students' language learning styles with different background information}

Hypothesis 1 was partially accepted because not all variables of background information affected students' language learning styles. There were significant differences at .05 level found in students' language learning styles as classified by gender, but no statistically significant differences in terms of field of study.

The overall mean score of language learning style of female students was higher than that of male students ( $\overline{\mathrm{X}}=3.46,3.33$ ). Both groups had language learning style at a moderate level. According to the results of the comparison of the mean scores of language learning styles, there were significant differences found in students' language learning styles between two groups (male and female) at .05 level. That is, female students had more language learning styles than male students. The results were shown in Table 2.

Table 2 A Comparison of Mean Scores of Students' Language Learning Styles Classified by Gender

\begin{tabular}{|c|c|c|c|c|c|c|c|c|}
\hline \multirow{2}{*}{$\begin{array}{l}\text { Language Learning Style } \\
\text { 1. Strategy-Orientation }\end{array}$} & \multicolumn{2}{|c|}{ Variable } & \multirow{2}{*}{$\frac{\mathbf{n}}{90}$} & \multirow{2}{*}{$\frac{\bar{X}}{3.41}$} & \multirow{2}{*}{$\begin{array}{r}\text { S.D. } \\
.42\end{array}$} & \multirow{2}{*}{$\begin{array}{c}\mathbf{d f} \\
201\end{array}$} & \multirow{2}{*}{$\frac{\mathbf{t}}{-.70}$} & \multirow{2}{*}{$\begin{array}{r}\text { Sig } \\
.48\end{array}$} \\
\hline & gender & male & & & & & & \\
\hline & & female & 113 & 3.45 & .42 & & & \\
\hline \multirow[t]{2}{*}{ 2. Meaning-Orientation } & gender & male & 91 & 3.26 & .50 & 204 & -1.48 & .14 \\
\hline & & female & 115 & 3.35 & .45 & & & \\
\hline \multirow[t]{2}{*}{ 3. Process-Orientation } & gender & male & 89 & 3.31 & .61 & 200 & -1.41 & .16 \\
\hline & & female & 113 & 3.42 & .47 & & & \\
\hline \multirow[t]{2}{*}{ 4. Failure-Resilience } & gender & male & 94 & 3.38 & .42 & 206 & $-3.45^{*}$ & .00 \\
\hline & & female & 114 & 3.59 & .47 & & & \\
\hline \multirow[t]{2}{*}{ Total } & gender & male & 84 & 3.33 & .34 & 190 & $-2.51 *$ & .01 \\
\hline & & female & 108 & 3.46 & .33 & & & \\
\hline
\end{tabular}

$* \mathrm{P}<.05$

The results in Table 3, obtained from applying the ANOVA, revealed that no difference in overall language learning style among three groups of field of study was found statistically significant at .05 level. This means that field of study had no impact on students' language learning style. However, the results showed that there was a statistically significant difference found in the students' language learning style in terms of failure-resilience (item no. 4) at level of .05 .

Table 3 Analysis of Variance of Students' Language Learning Styles Classified by Field of Study

\begin{tabular}{|c|c|c|c|c|c|c|}
\hline Language Learning Style & Variance & df & SS & MS & $\mathbf{F}$ & Sig. \\
\hline \multirow[t]{3}{*}{ 1. Strategy-Orientation } & Between Groups & 2.00 & .26 & .13 & .75 & .47 \\
\hline & Within Groups & 197.00 & 34.02 & .17 & & \\
\hline & Total & 199.00 & 34.28 & & & \\
\hline \multirow[t]{3}{*}{ 2. Meaning-Orientation } & Between Groups & 2.00 & .25 & .12 & .55 & .58 \\
\hline & Within Groups & 200.00 & 44.63 & .22 & & \\
\hline & Total & 202.00 & 44.88 & & & \\
\hline \multirow[t]{3}{*}{ 3. Process-Orientation } & Between Groups & 2.00 & .61 & .31 & 1.05 & .35 \\
\hline & Within Groups & 196.00 & 56.93 & .29 & & \\
\hline & Total & 198.00 & 57.54 & & & \\
\hline \multirow[t]{3}{*}{ 4. Failure-Resilience } & Between Groups & 2.00 & 1.79 & .89 & $4.40 *$ & .01 \\
\hline & Within Groups & 202.00 & 40.96 & .20 & & \\
\hline & Total & 204.00 & 42.74 & & & \\
\hline \multirow[t]{3}{*}{ Total } & Between Groups & 2.00 & .51 & .25 & 2.22 & .11 \\
\hline & Within Groups & 186.00 & 21.33 & .11 & & \\
\hline & Total & 188.00 & 21.84 & & & \\
\hline
\end{tabular}

$* \mathrm{P}<.05$ 
When the Post Hoc test was applied, it was found that the failure-resilience style of students majoring in math was higher than those of students majoring in science and language arts as shown in Table 4.

Table 4 Test of the Mean Scores of Learning Styles in Terms of Failure-Resilience Classified by Field of Study

\begin{tabular}{lccc}
\hline Field of Study & $\begin{array}{c}\text { Science } \\
(\overline{\mathrm{X}}=3.41)\end{array}$ & $\begin{array}{l}\text { Math } \\
(\overline{\mathrm{X}}=3.62)\end{array}$ & $\begin{array}{c}\text { Language Arts } \\
(\overline{\mathrm{X}}=3.42)\end{array}$ \\
\hline $\begin{array}{l}\text { Science }(\overline{\mathrm{X}}=3.41) \\
\text { Math }(\overline{\mathrm{X}}=3.62)\end{array}$ & $.20^{*}$ & $.19^{*}$ \\
Language Arts $(\overline{\mathrm{X}}=3.42)$ & & \\
\hline$* \mathrm{P}<.05$ & & & \\
\hline
\end{tabular}

$* \mathrm{P}<.05$

2.2 Hypothesis 2 investigated the relationship between English background knowledge and language learning styles

The Pearson product-moment correlation coefficient test was used to find out whether there was a statistically significant relationship between English background knowledge and language learning styles. This hypothesis was accepted. Table 5 shows that there was a positive relationship between English background knowledge of EFL students and their language learning styles at .05 level. In other words, students who had high English background knowledge liked to apply a lot of language learning styles. On the other hand, students who had low English background knowledge did not like to apply a lot of language learning styles.

Table 5 Correlate Results for English Background Knowledge and Language Learning Styles

\begin{tabular}{lcc}
\hline Variable & English background knowledge & Language learning style \\
\hline English background knowledge & 1.00 & \\
Language learning style & $.15^{*}$ & 1.00 \\
\hline$* \mathrm{P}<.05$ & &
\end{tabular}

When all items were considered, the result showed that there was a positive relationship between English background knowledge of EFL students and their language learning styles in terms of strategy-orientation and processorientation (items no. 1 and 3) at .05 level. In other words, students who had high English background knowledge liked to apply a lot of strategy-orientation and process-orientation styles. On the other hand, students who had low English background knowledge did not like to apply these two learning styles. The results were show in Table 6.

Table 6 Correlate Results for English Background Knowledge and Language Learning Styles Shown in All Items

\begin{tabular}{|c|c|c|c|c|c|}
\hline Variable & $\begin{array}{c}\text { English } \\
\text { background } \\
\text { knowledge }\end{array}$ & $\begin{array}{l}\text { 1. Strategy- } \\
\text { Orientation }\end{array}$ & $\begin{array}{l}\text { 2. Meaning- } \\
\text { Orientation }\end{array}$ & $\begin{array}{l}\text { 3. Process- } \\
\text { Orientation }\end{array}$ & $\begin{array}{l}\text { 4. Failure- } \\
\text { Resilience }\end{array}$ \\
\hline $\begin{array}{l}\text { English background } \\
\text { knowledge }\end{array}$ & 1.00 & & & & \\
\hline 1. Strategy-Orientation & $.15^{*}$ & 1.00 & & & \\
\hline 2. Meaning-Orientation & .12 & .36 & 1.00 & & \\
\hline 3. Process-Orientation & $.17 *$ & .29 & .42 & 1.00 & \\
\hline 4. Failure-Resilience & -.03 & .33 & .41 & .30 & 1.00 \\
\hline
\end{tabular}

$* \mathrm{P}<.05$

\section{CONCLUSION}

The results of the research have shown the importance to determine students' cognitive learning styles. It was found that students who had high English background knowledge liked to apply a lot of language learning styles. 
Nevertheless, the students' language learning styles were at the moderate level. Thus, it is suggested that teachers should make students aware of their learning style preferences and different approaches to learning. It was found that the students were positive about failure-resilience, strategy-orientation, and process-orientation learning styles. Also, it was found that students who had high English background knowledge liked to apply a lot of strategy-orientation and processorientation styles. Therefore, teachers should encourage students to learn from their failures, demonstrate effective learning strategies, and use appropriate procedures in order to achieve enhanced learning outcomes. In addition, the findings indicated that the students expressed minor preference for meaning-orientation. They did not make their knowledge more systematic when they learned new facts or procedures. Therefore, it is necessary to encourage the students to stretch their learning styles to be more meaningful. Activities that focus on meaning-orientation such as organizing ideas and memorizing structures about grammar can help them learn language in a more meaningful way.

The finding also revealed that difference did exist in learning styles among the students from different background. There were significant differences in language learning styles between male and female students. The mean scores for the male were lower in all styles. Also, a significant difference was found in the failure-resilience learning style among students from different field of study. The mean scores of language learning styles in terms of failure-resilience of students majoring in science and language arts were lower than the mean score of students majoring in math. These differences should be reconsidered when teaching foreign language. In this case, more emphasis should be placed on male students and students majoring in science and language arts. These students should be encouraged to stretch their learning styles so that the students can learn effectively in various learning situations.

Therefore, it is important to consider differences among the students. In order to accommodate different learning styles in the classroom, lecturers should provide students with opportunities in reflecting upon their use of learning styles and in using different learning styles to help them become better learners.

\section{ACKNOWLEDGEMENT}

This research was sponsored by Bangkok University.

\section{AUTHOR INFORMATION}

Asst. Prof. Napaporn Srichanyachon received her M.A. (Theatre: Text and Production) from University of East Anglia in England and B.A. (English) with $1^{\text {st }}$ class honors from Silpakorn University in Thailand. She is currently a full-time lecturer of Language Institute, Bangkok University. She has written a textbook for ESP program and a number of instructional materials. Her area of interest in research is English teaching.

\section{REFERENCES}

1. Experiential Learning. (2002). Retrieved 13 February, 2010, from http://marktozer.blogspot.com/2007/ 05/experiential-learning.html

2. Harrison, A.W. \& Rainer, R. K. (1992). The influence of individual differences on skill in end-user computing. Journal of Management Information Systems, 9(2), 93-111.

3. Heineman, P. L. (1995). Cognitive versus learning style. Retrieved 13 February, 2010, from http://www.personality-roject.org/perproj/others/heineman/cog.htm

4. Honey, P. \& Mumford, A. (1992). The manual learning styles. Maidenhead: Peter Honey.

5. Kayes, D.C. (2005). Internal validity and reliability of Kolb's learning style inventory version 3 (1999). Journal of Business and Psychology, 20(2), 249-257.

6. Keefe, J. W. (1979). Learning style: An overview. NASSP's Student Learning Styles: Diagnosing and Prescribing programs, Reston, VA: National Association of Secondary School Principals, 1-17.

7. Keefe, J. W. (1991). Learning style: Cognitive and thinking skills. Reston, VA: National Association of Secondary School Principals.

8. Kolb, D. A. (1984). Experiential learning: Experience as the source of learning and development. Englewood Cliffs, New Jersey: Prentice Hall.

9. Kolb, D. A. (1981). Experiential learning theory and the learning style inventory: A reply to Freedman and Stumpf. Academy of Management Review, 6(2), 289-296. 
10. Kolb, D. A. (1985). Learning style inventory. Boston: McBer and Company.

11. Liu, Y. \& Ginther, D. (1999). Cognitive styles and distance education. Online Journal of Distance Learning Administration, 2(3).

12. McFadden, E.A. (1986). Clinical decision making and its relationship to learning style and personality type. Unpublished doctoral dissertation, University of Maryland.

13. Messick, S. (1970). The criterion problem in the evaluation of instruction: Assessing possible, not just intended outcomes. In M.C. Wittrock \& D.E. Wiley (Eds.), The Evaluation of Instruction: Issues and Problems, 183-220. New York, NY: Holt Rinehart and Winston.

14. Mulalic, A., Shah P. M., \& Ahmad, F. (2009). Perceptual learning styles of ESL students. European Journal of Social Sciences, 7(3).

15. Pask, G. (1976). Styles and strategies of learning. British Journal of Educational Psychology. 46, 128- 148.

16. Riding, R. \& Rayner, S. G. (1998). Cognitive styles and learning strategies. London: David Fulton Publisher.

17. Rubin, J. \& Thompson, I. (1994). How to be more successful language learner. Boston: Heinle \& Heinle.

18. Shwalb, D. W., Nakazawa, J., \& Shwalb, B. L. (2005). Applied developmental psychology. Greenwich, Connecticut: Information Age.

19. Stash, N. (2007). Incorporating cognitive/learning styles in a general-purpose adaptive hypermedia system. SIKS Dissertation Series No. 2007-11, Technische Universiteit Eindhoven, the Netherlands.

20. Sternberg, R. J. (1999). Thinking styles. Cambridge: Cambridge University.

21. Tyacke, M. (1998). Learning style diversity and the reading class: Curriculum design and assessment in Reid, J. M., ed. Understanding Learning Styles in the Second Language Learning Classroom, 34-45. New Jersey: Prentice Hall.

22. Vermunt, J. D. (1996). Metacognitive, cognitive and affective aspects of learning styles and strategies: A phenomenographic analysis. Higher Education, 31, 25-50.

23. Witkin, H. A. (1950). Individual differences in ease of perception of embedded figures. Journal of Personality, 19, 1-15.

24. Wolfe, R. N., \& Johnson, S. D. (1995). Personality as a predictor of college performance. Educational and Psychological Measurement, 55, 177-185. 


\section{NOTES}

